\title{
A Bombardier Beetle Pheropsophus aequinoctialis (L.) (Insecta: Coleoptera: Carabidae) ${ }^{1}$
}

\author{
Gregory Parrow and Adam Dale ${ }^{2}$
}

\section{Introduction}

Pheropsophus aequinoctialis (L.) is a carabid beetle in the tribe Brachinini that is native to parts of South and Central America (Frank et al. 2009). Ground beetles of this tribe are commonly referred to as bombardier beetles due to their ability to produce a powerful and hot defensive chemical spray directed at would-be predators (Ferreira and Terra 1989). This spray is capable of harming humans, resulting in discomfort, physical burns (due to the spray temperature), and possibly contact dermatitis. In rare cases, systemic reactions requiring more urgent medical attention have been reported (Pardal et al. 2016). The adults of this species (Figure 1) are nocturnal and believed to be generalist predators and scavengers. However, larval stages (Figures 2 and 3) appear to depend on an exclusive diet of mole cricket eggs (Frank et al. 2009). As such, Pheropsophus aequinoctialis is considered to have potential use as a biological control agent against certain invasive mole cricket pests in North America (Frank et al. 2009).

\section{Distribution}

Literature suggests that this insect was historically found primarily in north and northeastern Brazil (Ferreira and Terra 1989). Now, Pheropsophus aequinoctialis is reported to inhabit various countries in Central and South America, in an area spanning Mexico (Yucatán) to parts of Argentina (Jujuy province) (Frank et al. 2009). Pheropsophus aequinoctialis typically inhabits riverbanks, sandbars, or in soils adjacent to bodies of freshwater, areas where Neoscapteriscus mole cricket species also inhabit (Frank et al. 2009).

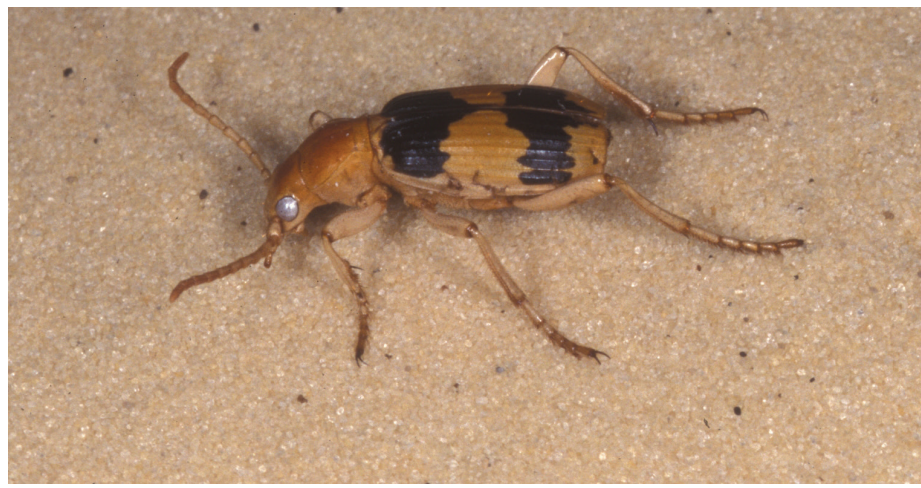

Figure 1. Adult Pheropsophus aequinoctialis.

Credits: Lyle Buss, UF/IFAS

\section{Life Cycle}

\section{Eggs}

Pheropsophus aequinoctialis eggs are white in color and have an elongate profile with slightly rounded ends. When magnified, the egg's surface appears highly perforated, displaying numerous polygonal facets (Frank et al. 2009). Under laboratory conditions, eggs hatch on average 13.5 days after oviposition, and captive females have been observed laying between 5 to 83 eggs per week (Weed 2003).

1. This document is EENY-765, one of a series of the Entomology and Nematology Department, UF/IFAS Extension. Original publication date September 2020. Visit the EDIS website at https://edis.ifas.ufl.edu for the currently supported version of this publication. This document is also available on the Featured Creatures website at http://entomology.ifas.ufl.edu/creatures.

2. Gregory Parrow; and Adam Dale, assistant professor, Entomology and Nematology Department; UF/IFAS Extension, Gainesville, FL 32611.

The Institute of Food and Agricultural Sciences (IFAS) is an Equal Opportunity Institution authorized to provide research, educational information and other services

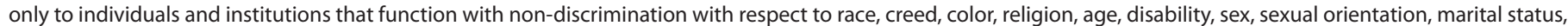

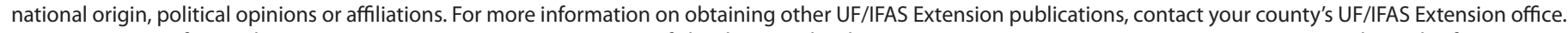
U.S. Department of Agriculture, UF/IFAS Extension Service, University of Florida, IFAS, Florida A \& M University Cooperative Extension Program, and Boards of County Commissioners Cooperating. Nick T. Place, dean for UF/IFAS Extension. 


\section{Larvae}

Larvae take approximately 10 days to develop to final instar larvae after hatching from eggs. There are three distinct larval instars for Pheropsophus aequinoctialis and all have a white body, an eyeless, cream colored head, and darkened mandibular (chewing) mouthparts (Figures 2 and 3) (Frank et al. 2009). However, Pheropsophus aequinoctialis undergoes what is known as hypermetamorphosis whereby the first and subsequent juvenile forms (instars) look markedly different from one another (beyond the typical size increase seen between molts in most immature insects). Specifically, the first instars of Pheropsophus aequinoctialis have longer legs and a narrower body than those of subsequent instars (Weed 2003).

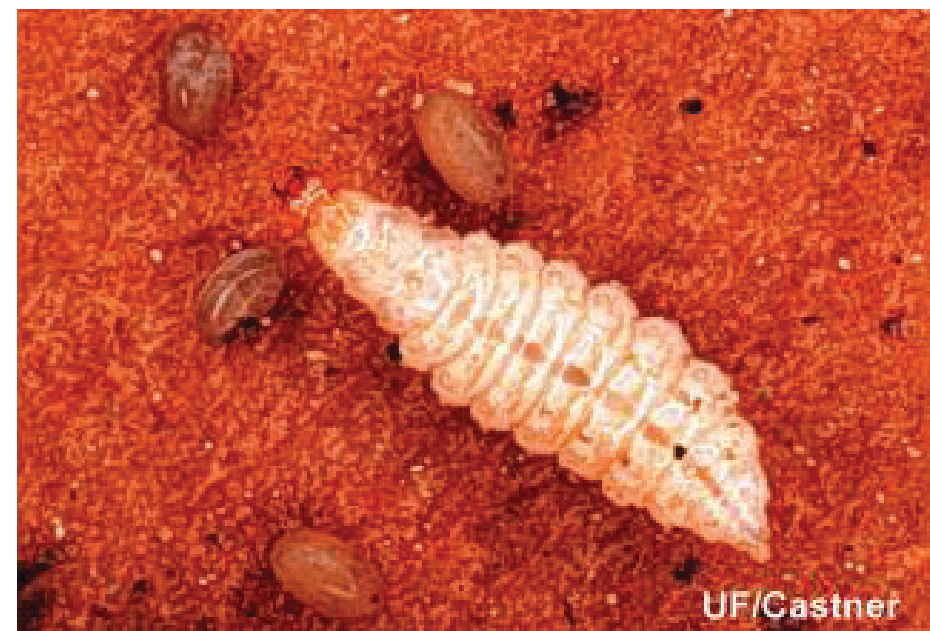

Figure 2. Large larval Pheropsophus aequinoctialis pictured next to mole cricket eggs.

Credits: James Castner, UF/IFAS

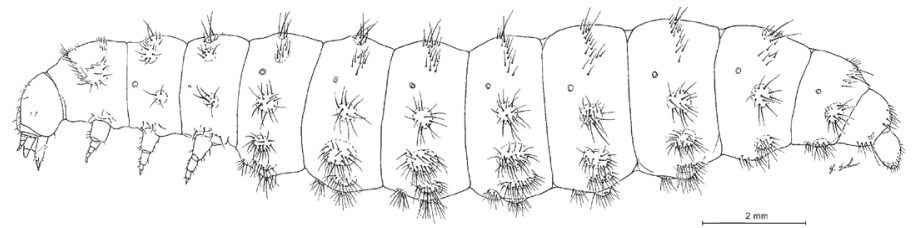

Figure 3. Habitus (left lateral aspect) of Pheropsophus aequinoctialis, third instar with legs shown. (Frank et al. 2009).

Credits: Creative Commons Attribution 3.0 Unported

\section{Pupae}

The pupal stage of Pheropsophus aequinoctialis is described as being typical of most carabid beetle species (Frank et al. 2009). As in most carabid beetles, the pupa (Figure 4) is of an exarate form whereby its appendages are free and without a cocoon covering them (Singh 2006). The total time from pupation to adult is approximately 20 days (Frank et al. 2009).
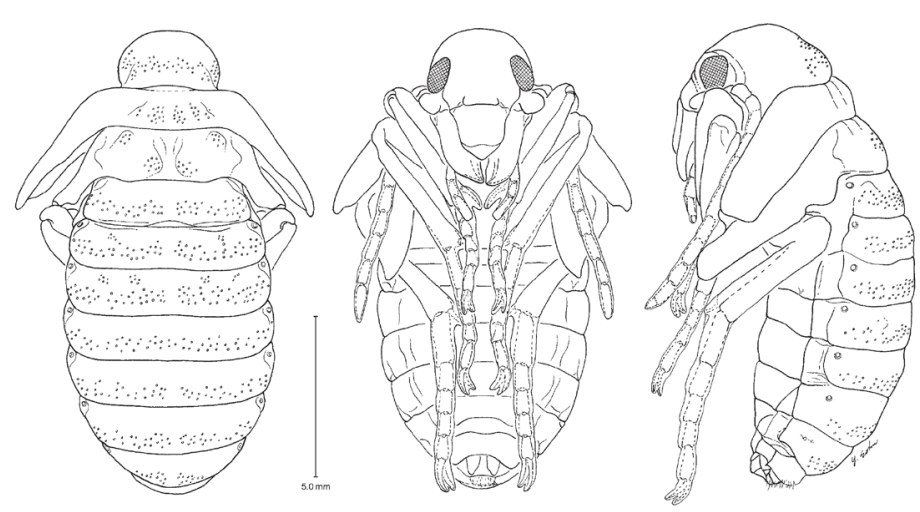

Figure 4. Pupa of Pheropsophus aequinoctialis (Frank et al. 2009). Credits: Creative Commons Attribution 3.0 Unported

\section{Adults}

Adults are typically between $15-20 \mathrm{~mm}$ long with a predominantly yellow to reddish head and body (Figure 1). The hardened wing covers (elytra) typically show two large black spots, joining along the divide (suture) where the elytra meet (Bouchard 2014).

\section{Behavior}

Adult female Pheropsophus aequinoctialis actively seek and deposit eggs in (or around) the burrows of mole crickets (Weed \& Frank ). The newly hatched first instar larva is especially mobile compared to other larval instars, which helps it search for eggs to feed on inside the mole cricket burrow egg chambers (Weed 2003). On average, juvenile Pheropsophus aequinoctialis have been observed consuming over 38 mole cricket eggs prior to completing development. After feeding and completing the three larval instars, juveniles will pupate in the same egg chambers where they were feeding and any successfully emerging adults must dig their way out of the soil (Weed 2003).

As adults, all beetles in the coleopteran suborder, Adephaga (of which Pheropsophus aequinoctialis belongs) have specialized abdominal "pygidial glands" that produce defensive compounds and help deter predators. These glands are composed of cells for secreting defensive chemicals, a pair of canals for transporting secretions, and a pair of reservoirs for storing them until released (Giglio et al. 2011). In addition, bombardier beetles have evolved internal structures including specialized valves, contracting musculature, and a hardened "reaction chamber", among other traits. These structures enable bombardier beetles to controllably mix multiple chemical reactants within the reaction chamber, producing rapid and violent exothermic reactions, or those that release energy through heat (Giglio et al. 2015). The result is a fine mist accompanied by audible "popping" sounds emitted from the tip of the 
bombardier's abdomen, which the beetle can aim like a turret in any direction (Eisner 1958, Dean et al. 1990). Most predators are instantaneously repelled or worse - the spray of bombardier beetles has been observed to also disorient, induce seizures, or cause obsessive self-grooming behavior on would-be attackers (Eisner 1958).

In terms of diet, adult Pheropsophus aequinoctialis is omnivorous and has been observed feeding on various insects, fruits, and vegetation. However, juveniles appear to be entirely dependent upon a diet of mole cricket eggs for survival. As evidence of this dependency, researchers attempting to rear the beetle under laboratory conditions found that newly hatched Pheropsophus aequinoctialis larvae would only initiate feeding when located within a sandy cell or pit that mimicked a mole cricket chamber (Frank et al. 2009). Some have speculated that adult female beetles are guided in egg laying towards mole crickets by detecting possible cues from the tunnels (Weed 2003), which if true, would further demonstrate the beetle's larval dependence upon mole crickets.

\section{Economic and Environmental Importance}

In its native range, Pheropsophus aequinoctialis is not considered a pest or otherwise economically important. However, releasing Pheropsophus aequinoctialis beyond its native habitat has been proposed as a potential biological control tactic, particularly in the southeastern United States where three invasive mole cricket species are considered damaging pests to the cattle and turfgrass industries (Walker \& Nickle 1981). Three other biological control agents were introduced to control these pests and have largely been considered a success (Parkman et al. 1996; Frank et al. 2006; Mhina et al. 2016). The Mole Cricket Biological Control Program (MCBCP) at the University of Florida considered Pheropsophus aequinoctialis as a potential biological control tool, but the program ended before researchers were able to reach conclusions about the beetle's potential impact on non-target organisms.

Another reason Pheropsophus aequinoctialis was never released is due to concerns about impacts on a native mole cricket species. The northern mole cricket (Neocurtilla hexadactyla), is native to the eastern United States and not considered a pest (Frank et al. 2009). The eggs of this mole cricket species were shown in laboratory conditions to be a successful diet for Pheropsophus aequinoctialis larvae, generating concern that it could be attacked in the wild. However, unlike mole crickets in the genus Neoscapteriscus, adult female Neocurtilla mole crickets are thought to actively monitor and defend their egg clutches, a trait that might reduce risks associated with introducing Pheropsophus aequinoctialis into the mole cricket's natural range (Frank et al. 2009). Aside from concerns about the beetle's effects on the northern mole cricket, Pheropsophus aequinoctialis adults were also found to be phoretic carriers of nematodes, mites, and fungi, which raised concerns about potential ancillary introductions of other exotic organisms (Frank et al. 2009). Risks associated with accidentally introducing an invasive pest (or associated pathogen) by way of Pheropsophus aequinoctialis warrants further research before using the beetle as a biological control agent in the United States. Still, other biological control organisms (e.g. Steinernema scapterisci, Larra bicolor) released under the MCBCP have established self-sustaining populations and saved Florida's cattle industry an estimated \$13 million annually since their establishment (Mhina et al. 2016). One possible advantage of using Pheropsophus aequinoctialis is that its natural riverine/water habitat may allow pest managers to avoid pesticides in these areas, which can pose risks to aquatic life (Frank et al. 2009). Therefore, Pheropsophus aequinoctialis may have additional untapped economic benefits to supplement existing mole cricket control programs.

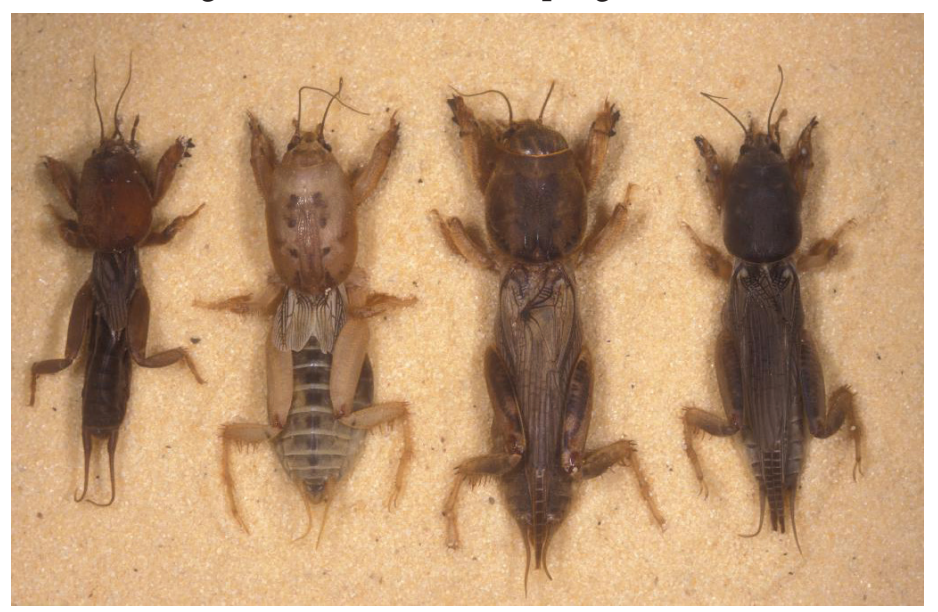

Figure 5. From left to right: northern mole cricket (Neocurtilla hexadactyla), short winged mole cricket (Neoscapteriscus abbreviatus), tawny mole cricket (Neoscapteriscus vicinus), and southern mole cricket (Neoscapteriscus borellii).

Credits: Lyle Buss, UF/IFAS

\section{Selected References}

Bouchard P., V. E. Arthur, and L. T. Stephane. 2014. The Book of Beetles: A Life-size Guide to Six Hundred of Nature's Gems. Chicago, IL: University of Chicago Press.

Dean J., D. J. Aneshansley, H. E. Edgerton, and T. Eisner. 1990. "Defensive spray of the bombardier beetle: A biological pulse jet." Science 248 (4960): 1219-1221. 
Ferreira C., and W. Terra. 1989. "Spatial organization of digestion, secretory mechanisms and digestive enzyme properties in Pheropsophus aequinoctialis (Coleoptera: Carabidae)." Insect Biochemistry 19:383-391.

Frank J. H., and T. J. Walker. 2006. "Permanent control of pest mole crickets (Orthoptera: Gryllotalpidae: Scapteriscus) in Florida." American Entomologist 52 (3): 138-144.

Frank J. H., T. L. Erwin, and R. C. Hemenway. 2009. "Economically beneficial ground beetles. The specialized predators Pheropsophus aequinoctialis (L.) and Stenaptinus jessoensis (Morawitz): Their laboratory behavior and descriptions of immature stages (Coleoptera: Carabidae: Brachininae)." ZooKeys 14:1-36.

Giglio A., P. Brandmayr, F. Talarico, and T. Z. Brandmayr. 2011. "Current knowledge on exocrine glands in carabid beetles: structure, function and chemical compounds." ZooKeys 100:193-201.

Giglio A., M. Muzzi, and R. Romani. 2015. "Functional anatomy of the explosive defensive system of bombardier beetles (Coleoptera, Carabidae, Brachininae)." Arthropod Structure and Development 44:468-490.

Mhina G. J., N. C. Leppla, M. H. Thomas, and D. Solis. 2016. "Cost effectiveness of biological control of invasive mole crickets in Florida pastures." Biological Control 100:108-115.

Pardal P. P., C. T. Silva, W. M. Monteiro, and M. A. Gadelha. 2016. "Dermatitis after contact with Pheropsophus sp (Coleoptera, Carabidae, Brachininae) in the Pará State, Brazilian Amazon." Revista da Sociedade Brasileira de Medicina Tropical 49:799-801.

Parkman J. P., J. H. Frank, T. J. Walker, and D. J. Schuster. 1996. "Classical biological control of Scapteriscus spp. (Orthoptera: Gryllotalpidae) in Florida." Environmental Entomology 25:1415-1420

Singh R. 2006. Post embryonic development. P. 170 In Singh R. Elements of Entomology. Rastogi Publications. Meerut India.

Walker T. J., and D. A. Nickle. (1981). "Introduction and spread of pest mole crickets: Scapteriscus vicinus and S. acletus reexamined." Annals of the Entomological Society of America 74:158-163
Weed A. S., and J. H. Frank. 2005. "Oviposition behavior of Pheropsophus aequinoctialis L. (Coleoptera: Carabidae): A natural enemy of Scapteriscus mole crickets (Orthoptera: Gryllotalpidae)." Journal of Insect Behavior 18:707-723.

Weed A. S. 2003. Reproductive strategy of Pheropsophus aequinoctialis L.: Fecundity, fertility, oviposition behavior; and influence of mole cricket egg chamber depth on larval survival. MS thesis. Gainesville: University of Florida Institute of Food and Agricultural Sciences. 